\title{
Viability and Dormancy of Rice Seeds after Storage and Pre-Treatment with Dry Heat and Chemical Agents
}

\author{
Yvonne A. Mutinda ${ }^{1}$, James W. Muthomi ${ }^{1}$, John M. Kimani ${ }^{2}$, George N. Cheminigw'wa ${ }^{1} \&$ Florence M. Olubayo $^{1}$ \\ ${ }^{1}$ Department of Plant Science and Crop Protection, University of Nairobi, Nairobi, Kenya \\ ${ }^{2}$ Industrial Crops Research Institute, Kenya Agricultural and Livestock Research Organization, Mwea, Kenya \\ Correspondence: Yvonne A. Mutinda, Department of Plant Science and Crop Protection, University of Nairobi, \\ P.O. Box 29053-00625, Nairobi, Kenya. Tel: 254-(0)-711-631-069. E-mail: agnesvonne@gmail.com
}

\author{
Received: March 26, $2017 \quad$ Accepted: May 2, $2017 \quad$ Online Published: June 15, 2017 \\ doi:10.5539/jas.v9n7p175 URL: https://doi.org/10.5539/jas.v9n7p175
}

\begin{abstract}
Inappropriate seed packaging and seed dormancy affects seed quality and consequently leads to reduced crop stand, low seedling vigour and reduced yields. The objective of the study was to determine the effect of seed packaging material and seed treatment on viability and dormancy in rice seeds. Effect of packaging material was evaluated by storing freshly harvested seeds of Basmati 370 and BW 196 varieties in polythene, khaki, cheese cloth, polypropylene $(\mathrm{Pp})$ sack and gunny bag sat room temperature and at $6{ }^{\circ} \mathrm{C}$ for six months. Effect of seed treatment on dormancy was determined by pre-treatment of seeds with nitric acid at $0.1 \mathrm{M}, 0.2 \mathrm{M}, 0.5 \mathrm{M}, 1 \mathrm{M}$ and $2 \mathrm{M}$, gibberellic acid $\left(\mathrm{GA}_{3}\right)$ at $1000 \mathrm{ppm}, 2000 \mathrm{ppm}$ and $5000 \mathrm{ppm}$, and hydrogen peroxide at $0.5 \mathrm{M}, 1 \mathrm{M}, 2$ $\mathrm{M}, 3 \mathrm{M}, 5 \mathrm{M}$ and dry heat at $50{ }^{\circ} \mathrm{C}$ for 48 hours. The seeds were subjected to germination test on moist paper and data on percentage germination, seedling length and seedling dry weight were taken. Packaging material had a significant $(\mathrm{P} \leq 0.05)$ effect on germination and vigour. At room temperature, seed stored in polythene bag had the highest germination 88.2\% and 57.8\% for BW 196 and Basmati 370, respectively. Basmati 370 in khaki bag stored in the cold room had the highest germination 48.3\%, while BW 196 stored in polythene had the highest $(86.0 \%)$. Pre-treatment of seeds reduced dormancy, with variety BW 196 showing the highest germination of up to $67 \%$, while variety Basmati 370 had the lowest germination of up to $40 \%$. Gibberellic acid $\left(\mathrm{GA}_{3}\right)$ at $5000 \mathrm{ppm}$ was the most effective in breaking seed dormancy resulting in up to $95.7 \%$ germination. The results of the study indicated that packaging rice seed in polythene bags for periods not exceeding six months and pre-treatment with $\mathrm{GA}_{3}$ maintains high seed viability and breaks dormancy, respectively, thus ensuring rapid and uniform germination of vigorous seedlings. This would reduce the period farmers have to wait after harvest before they can plant newly harvested rice seeds.
\end{abstract}

Keywords: rice, seed quality, dormancy, packaging material, viability

\section{Introduction}

Rice is a key food security crop in many countries. In Kenya, rice is produced by small-scale farmers as an income generating crop (USAID, 2010). Despite the increasing demand for rice, yields have been low (Emomg'or et al., 2009). Some of the factors contributing to low yields include pests and diseases, low-quality seeds, water scarcity and lack of appropriate storage facilities (Ministry of Agriculture, 2009; Onyango, 2014). Seed deterioration starts immediately after harvest and therefore, post-harvest handling of rice seed plays a key role in the maintenance of seed quality (Vange et al., 2016). It is important to preserve the genetic integrity of seeds during storage to retain high seed quality (Pradhan \& Badola, 2012). Factors that affect the quality of seed during storage include drying temperature, moisture content, storage temperature, oxygen supply, pest and diseases, packaging material and duration of storage (Muangkaeo et al., 2005; Chattah et al., 2012; Jyoti \& Malik, 2013). Storage temperature and moisture content are the most crucial (Pradhan \& Badola, 2012). The optimum moisture content for storing rice seed is between 12-14\% (Whitehouse et al., 2015). However, reduction in storage temperature and seed moisture content has been shown to increase seed storage time (Mbofung et al., 2013). Therefore, to achieve acceptable levels of germination and vigour, proper packaging is crucial as inappropriate packaging material leads to deterioration in the quality of seed during storage (Naguib et al., 2011). Loss of germination, reduction in vigour, and accumulation of pests and disease may occur due to poor storage conditions (Vange et al., 2016). 
Seed dormancy is a temporary condition whereby mature and viable seeds fail to germinate up to a specific time under favourable conditions (Kumar et al., 2009; Tung \& Serrano, 2011; Aliloo \& Darabinejad, 2013; Nasreen et al., 2015). Dormancy helps to prevent losses due to germination during harvesting and storage in case of unfavourable weather (Kumar et al., 2009; Wu et al., 2016). Dormancy in rice can be due to thick seed coat or embryo factors (Seshu \& Dadlani 1991). Seed dormancy in genetically controlled and in rice varieties such as Basmati 370, dormancy is controlled by a recessive gene (Kumar et al., 2009). The dormancy in Basmati 370 can last up to 50 days after harvest (Kumar et al., 2009). The degree of dormancy in different rice varieties varies greatly and is influenced by genes, duration of maturity and environment (Tung \& Seranno, 2011). In some varieties, the level of dormancy is weaker while other varieties tend to have strong dormancy (Waheed et al., 2012). However, dormancy in rice seed is sometimes a problem to farmers because it affects rapid, uniform seed germination and vigour during the early stages of crop growth thereby reducing productivity (Waheed et al., 2012; Tung \& Serrano, 2011). Therefore, breaking seed dormancy helps to increase uniformity in germination and shorten the time required for seeds to germinate. The objective of the study was to evaluate the effect of different packaging materials and seed treatment on viability and dormancy in rice seeds.

\section{Materials and Methods}

\subsection{Determination of the Effect of Different Packaging Materials on Seed Germination and Vigor}

Two rice varieties, Basmati 370 and BW 196 which were less than one-month old were used. The seeds were cleaned and dried to constant moisture content before storage. The initial moisture content was recorded using agraTronix MT-16 Grain Moisture Tester. The moisture content for Basmati 370 was 11.1\%, while that for BW 196 was $12.5 \%$. Initial germination test was carried out before seeds were stored in the different materials. The seeds were divided into $250 \mathrm{~g}$ and packed in khaki, polythene, cheese cloth, Polypropylene (Pp) sack and gunny bags. Some of the seeds were stored at room temperature $\left(25^{\circ} \mathrm{C}\right)$ and the other lot in a cold room at $6{ }^{\circ} \mathrm{C}$ for a period of six months. Determination of germination was done at a one-month interval. After 20 days, 10 randomly selected seedlings were taken and root and shoot length measured in centimetres (Islam et al., 2012). The seedlings were then dried at $50{ }^{\circ} \mathrm{C}$ for 24 hours and dry weight for all three replications was taken. Data was collected on percentage germination, seedling length and seedling dry weight.

\subsection{Determination of Effect of Seed Treatment on Rice Seed Dormancy}

Freshly harvested seed samples of two rice varieties, BW 196 and Basmati 370 were pre-soaked in $0.1 \mathrm{M}, 0.2 \mathrm{M}$, $0.5 \mathrm{M}, 1 \mathrm{M}$ and $2 \mathrm{M} \mathrm{HNO}_{3}, 1000 \mathrm{ppm}, 2000 \mathrm{ppm}$ and $5000 \mathrm{ppm} \mathrm{GA} 3$ and $0.5 \mathrm{M}, 1 \mathrm{M}, 2 \mathrm{M} 3 \mathrm{M}$ and $5 \mathrm{M} \mathrm{H}_{2} \mathrm{O}_{2}$ or subjected to dry heat at $50{ }^{\circ} \mathrm{C}$ for two days. The treated seeds were then dried at room temperature for one hour before they were subjected to germination test by planting on a paper towel (Waheed et al., 2012). The seeds were planted using on top of paper method at room temperature under alternating 12 hours of light and darkness. The experiment was laid out in Completely Randomized Design (CRD) with the chemicals and dry heat as the treatments and three replicates of 50 seeds was used for each treatment. Germination was monitored over a period of 14 days and data collected was on germination and seedling length. After 20 days 10 seedlings were randomly selected from each replication and the seedling length was measured in centimetres. The seedling length was then used for the calculation of the vigor index. Germination was considered as the emergence of the radicle. Seeds with germination percentage $\leq 25 \%$ were considered strongly dormant and those with $\geq 50 \%$ were considered weakly dormant (Naredo et al., 1998).

\subsection{Data Analysis}

Germination percentage was calculated using the formula below (Vange et al., 2016; Islam et al., 2012):

$$
\text { Germination }(\%)=\left(\frac{\text { Number of Germinated Seeds }}{\text { Total Number of Seeds Planted }}\right) \times 100
$$

This was used to calculate the seedling vigor index (SVI) using the formula below (Aliloo \& Darabinejad, 2013).

$$
\mathrm{SVI}=\frac{\text { Germination } \% \times \text { Seedling Length }}{100}
$$

Speed Germination Index (SGI) was also computed as shown below (Ali et al., 2011):

$$
\text { SGI }=\frac{\text { Number of Germinated Seeds }}{\text { Days of } 1^{\text {st }} \text { Count }}+\frac{\text { Number of Germinated Seed }}{\text { Days of Final Count }}
$$

Data was subjected to analysis of variance (ANOVA) using GENSTAT $15^{\text {th }}$ edition and mean separation was done using Fischer's Protected Least Significant Difference (LSD) at 5\% level of significance. 


\section{Results}

\subsection{Effect of Different Packaging Materials on Seed Germination and Vigour}

The packaging materials had a significant effect on seed germination under the two storage temperatures. Seeds stored at room temperature had a 5.3\% higher germination than those in cold storage (Tables 1 and 2). Seeds packaged in cheese cloth and polythene had significantly higher germination for variety BW 196. Significantly lower germination was observed in seeds of variety Basmati 370 compared to BW 196 . Over $50 \%$ of the seeds of Basmati 370 did not germinate and remained hard. Seeds stored in poly sacks had the lowest germination under both temperatures for both varieties. The type of packaging material had an effect on the percentage of abnormal seedling, mouldiness and seed infection for seeds stored at both cold and room temperature. Packaging the seeds in both cheese cloth and polythene also resulted in a significantly higher percentage of normal seedlings. Seedling viability and infection were not significantly variable in both temperature and under all packaging materials (Tables 1 and 2).

Variety BW 196 recorded higher dry weight and seedling length as compared to Basmati 370 under both room temperature and at $6{ }^{\circ} \mathrm{C}$ (Table 3; Figure 1). Storing seed at cold temperature resulted in seedlings that were less vigorous, with low seedling weight and seedling length. Seeds stored at room temperature resulted in seedlings with up to $52 \%$ and $105 \%$ increase in dry weight for Basmati 370 and BW 196 as compared to the seedlings from seeds stored at $6{ }^{\circ} \mathrm{C}$ (Figure 1). Storing seed at room temperature resulted in up to $24 \%$ increase in seedling length for both Basmati 370 and BW 196 rice varieties. There were significant differences among the packaging materials in seedling dry weight and seedling length for Basmati 370 seed stored at room temperature (Table 3). Seeds of Basmati 370 stored in gunny bags at room temperature resulted in seedlings with up to $50 \%$ less dry weight compared to seeds stored in cheese cloth, polythene and khaki packaging.

Table 1. Percentage of viable rice seeds stored in different packaging materials under cold storage

\begin{tabular}{lllllll}
\hline Variety/P.M. & Germinated & Normal & Abnormal & Mouldy & Hard & Infected \\
\hline Cheese cloth & $44.9 \mathrm{~d}$ & $44.0 \mathrm{~d}$ & $0.9 \mathrm{a}$ & $3.3 \mathrm{ab}$ & $54.0 \mathrm{~b}$ & $4.3 \mathrm{a}$ \\
Gunny & $46.6 \mathrm{~d}$ & $45.4 \mathrm{~d}$ & $1.1 \mathrm{a}$ & $4.3 \mathrm{a}$ & $54.4 \mathrm{~b}$ & $7.4 \mathrm{a}$ \\
Khaki & $48.3 \mathrm{~d}$ & $46.7 \mathrm{~d}$ & $1.7 \mathrm{a}$ & $3.7 \mathrm{a}$ & $51.7 \mathrm{~b}$ & $5.4 \mathrm{a}$ \\
Polythene & $47.9 \mathrm{~d}$ & $46.8 \mathrm{~d}$ & $1.2 \mathrm{a}$ & $3.8 \mathrm{a}$ & $52.1 \mathrm{~b}$ & $6.7 \mathrm{a}$ \\
Pp sack & $37.2 \mathrm{e}$ & $36.1 \mathrm{e}$ & $1.1 \mathrm{a}$ & $4.2 \mathrm{a}$ & $62.8 \mathrm{a}$ & $4.0 \mathrm{a}$ \\
\hline Cheese cloth & $82.4 \mathrm{a}$ & $80.8 \mathrm{a}$ & $1.6 \mathrm{a}$ & $2.7 \mathrm{~b}$ & $17.6 \mathrm{~d}$ & $6.6 \mathrm{a}$ \\
Gunny & $79.6 \mathrm{~b}$ & $78.0 \mathrm{~b}$ & $1.6 \mathrm{a}$ & $3.6 \mathrm{a}$ & $20.4 \mathrm{~d}$ & $5.4 \mathrm{a}$ \\
Khaki & $81.0 \mathrm{ab}$ & $79.8 \mathrm{ab}$ & $1.2 \mathrm{a}$ & $4.2 \mathrm{a}$ & $18.8 \mathrm{~d}$ & $5.0 \mathrm{a}$ \\
Polythene & $86.0 \mathrm{a}$ & $84.7 \mathrm{a}$ & $1.3 \mathrm{a}$ & $2.7 \mathrm{~b}$ & $14.0 \mathrm{~d}$ & $6.1 \mathrm{a}$ \\
Pp sack & $69.0 \mathrm{c}$ & $68.0 \mathrm{c}$ & $1.3 \mathrm{a}$ & $2.4 \mathrm{~b}$ & $31.0 \mathrm{c}$ & $3.1 \mathrm{a}$ \\
$-\mathrm{SD}$ & 18.0 & 17.9 & 0.2 & 0.7 & 18.0 & 1.3 \\
LSD $(\mathrm{P} \leq 0.05)$ & 5.43 & 5.1 & 1.32 & 2.07 & 5.27 & 6.08 \\
CV $(\%)$ & 5.2 & 5 & 59.4 & 24.6 & 8.7 & 25.1 \\
\hline
\end{tabular}

Note. P.M. = packaging material, Means followed by the same letter(s) in each column are not significantly different at $\mathrm{p} \leq 0.05, \mathrm{SD}=$ standard deviation, $\mathrm{LSD}=$ least significant difference at $5 \%, \mathrm{CV}=$ coefficient of variation. 
Table 2. Percentage of viable rice seeds stored in different packaging materials under room temperature

\begin{tabular}{|c|c|c|c|c|c|c|}
\hline & Germinated & Normal & Abnormal & Mouldy & Hard & Infected \\
\hline \multicolumn{7}{|l|}{ Basmati 370} \\
\hline Cheese cloth & $57.1 \mathrm{~d}$ & $56.0 \mathrm{c}$ & $1.2 \mathrm{a}$ & $5.3 \mathrm{a}$ & $39.6 \mathrm{c}$ & $5.2 \mathrm{a}$ \\
\hline Gunny & $57.1 \mathrm{~d}$ & $56.0 \mathrm{c}$ & $1.1 \mathrm{a}$ & $5.6 \mathrm{a}$ & $42.9 \mathrm{~b}$ & $4.0 \mathrm{a}$ \\
\hline Khaki & $44.7 \mathrm{e}$ & $43.4 \mathrm{c}$ & $1.1 \mathrm{a}$ & $5.3 \mathrm{a}$ & $55.3 \mathrm{a}$ & $5.6 \mathrm{a}$ \\
\hline Polythene & $57.8 \mathrm{~d}$ & $56.1 \mathrm{c}$ & $1.7 \mathrm{a}$ & $5.1 \mathrm{a}$ & $42.2 b$ & $5.2 \mathrm{a}$ \\
\hline Pp sack & $50.0 \mathrm{e}$ & $49.0 \mathrm{c}$ & $1.0 \mathrm{a}$ & $5.3 \mathrm{a}$ & $49.6 \mathrm{a}$ & $5.6 \mathrm{a}$ \\
\hline \multicolumn{7}{|l|}{$B W 196$} \\
\hline Cheese cloth & $84.0 \mathrm{ab}$ & $82.9 \mathrm{a}$ & $1.1 \mathrm{a}$ & $4.7 \mathrm{a}$ & $16.0 \mathrm{de}$ & $4.2 \mathrm{a}$ \\
\hline Gunny & $81.1 \mathrm{bc}$ & $79.7 \mathrm{a}$ & $1.4 \mathrm{a}$ & $4.4 \mathrm{a}$ & $18.9 \mathrm{~d}$ & $3.2 b$ \\
\hline Khaki & $78.4 \mathrm{c}$ & $77.0 \mathrm{a}$ & $1.3 \mathrm{a}$ & $3.8 \mathrm{a}$ & $21.6 \mathrm{~d}$ & $4.9 \mathrm{a}$ \\
\hline Polythene & $88.2 \mathrm{a}$ & $87.2 \mathrm{a}$ & $1.0 \mathrm{a}$ & $4.4 \mathrm{a}$ & $11.7 \mathrm{e}$ & $4.7 \mathrm{a}$ \\
\hline Pp sack & $77.1 \mathrm{c}$ & $75.4 b$ & $1.7 \mathrm{a}$ & $4.7 \mathrm{a}$ & $22.9 \mathrm{~d}$ & $4.6 \mathrm{a}$ \\
\hline $\mathrm{SD}$ & 14.9 & 14.8 & 0.3 & 0.5 & 14.7 & 0.7 \\
\hline $\operatorname{LSD}(\mathrm{P} \leq 0.05)$ & 5.88 & 10.88 & 1.05 & 3.65 & 7.57 & 1.98 \\
\hline $\mathrm{CV}(\%)$ & 5.2 & 4.7 & 51.1 & 39.6 & 13.9 & 26.6 \\
\hline
\end{tabular}

Note. P.M. = packaging material, Means followed by the same letter(s) in each column are not significantly different at $\mathrm{p} \leq 0.05, \mathrm{SD}=$ standard deviation, $\mathrm{LSD}=$ least significant difference at $5 \%, \mathrm{CV}=$ coefficient of variation.

Table 3. Dry weights and seedling lengths of two rice varieties stored at room temperature and cold storage

\begin{tabular}{|c|c|c|c|c|}
\hline & \multicolumn{2}{|c|}{ Room temperature } & \multicolumn{2}{|c|}{ Cold storage } \\
\hline & Dry weight (g) & Length (cm) & Dry weight (g) & Length (cm) \\
\hline \multicolumn{5}{|l|}{ Basmati 370} \\
\hline Cheese cloth & $0.8 \mathrm{~b}$ & $10.9 \mathrm{~d}$ & $0.4 \mathrm{~b}$ & $8.8 \mathrm{~d}$ \\
\hline Gunny & $0.4 \mathrm{c}$ & $10.3 \mathrm{de}$ & $0.4 \mathrm{~b}$ & $6.7 \mathrm{e}$ \\
\hline Khaki & $0.8 \mathrm{~b}$ & $9.7 \mathrm{e}$ & $0.5 \mathrm{~b}$ & $9.4 \mathrm{~d}$ \\
\hline Polythene & $0.8 b$ & $10.2 \mathrm{de}$ & $0.5 \mathrm{~b}$ & $9.2 \mathrm{~d}$ \\
\hline Pp ack & $0.7 b$ & $9.7 \mathrm{e}$ & $0.5 \mathrm{~b}$ & $8.1 \mathrm{de}$ \\
\hline \multicolumn{5}{|l|}{$B W 196$} \\
\hline Cheese cloth & $1.3 \mathrm{a}$ & $18.6 \mathrm{~b}$ & $0.7 \mathrm{a}$ & $13.5 \mathrm{c}$ \\
\hline Gunny & $1.4 \mathrm{a}$ & $16.2 \mathrm{c}$ & $0.7 \mathrm{a}$ & $13.1 \mathrm{c}$ \\
\hline Khaki & $1.5 \mathrm{a}$ & $19.1 \mathrm{a}$ & $0.7 \mathrm{a}$ & $18.1 \mathrm{a}$ \\
\hline Polythene & $1.5 \mathrm{a}$ & $19.8 \mathrm{a}$ & $0.7 \mathrm{a}$ & $15.6 \mathrm{~b}$ \\
\hline Pp sack & $1.3 \mathrm{a}$ & $16.7 \mathrm{c}$ & $0.6 \mathrm{a}$ & $12.2 \mathrm{c}$ \\
\hline $\mathrm{SD}$ & 0.4 & 4.1 & 0.1 & 3.5 \\
\hline $\operatorname{LSD}(\mathrm{P} \leq 0.05)$ & 0.24 & 1.02 & 0.1 & 1.92 \\
\hline CV\% & 13.7 & 4.2 & 10.5 & 9.8 \\
\hline
\end{tabular}

Note. Means followed by the same letter(s) in each column are not significantly different at $\mathrm{P} \leq 0.05, \mathrm{SD}=$ standard deviation, $\mathrm{LSD}=$ least significant difference at $5 \%, \mathrm{CV}=$ coefficient of variation.

\subsection{Effect of Physical and Chemical Seed Treatment on Rice Seed Dormancy}

Pre-treatment of seeds of both Basmati 370 and BW 196 rice varieties significantly $(\mathrm{P} \leq 0.05)$ improved germination percentage (Table 4). Chemical treatments improved seedling germination but dry heat inhibited germination in both varieties. There were significant $(\mathrm{P} \leq 0.05)$ differences among the different seed treatments. The most effective were pre-treatment of seeds with gibberellic acid $\left(\mathrm{GA}_{3}\right)$, nitric acid $\left(\mathrm{HNO}_{3}\right)$ and hydrogen peroxide $\left(\mathrm{H}_{2} \mathrm{O}_{2}\right)$ for both Basmati 370 and BW 196 rice varieties. Treatment with dry heat at $50{ }^{\circ} \mathrm{C}, 0.5 \mathrm{M}, 1 \mathrm{M}$ and $2 \mathrm{M} \mathrm{HNO}_{3}$ completely suppressed germination in both rice varieties (Table 4). Variety BW 196 had higher germination index than Basmati 370. The highest germination index was found on BW 196 treated with $1 \mathrm{M}$ $\mathrm{H}_{2} \mathrm{O}_{2}$ followed by Basmati 370 treated with $5000 \mathrm{ppm} \mathrm{GA}$. Pre-treatment of seeds with 1000-5000 ppm GA 3 
and $1 \mathrm{M}-5 \mathrm{M} \mathrm{H}_{2} \mathrm{O}_{2}$ enhanced germination percentage by up to $99 \%$ in both rice varieties. The most effective was 5000 ppm $\mathrm{GA}_{3}$, which enhanced germination percentage by over $300 \%$ for Basmati 370 . Nitric acid at $0.1 \mathrm{M}$ was as effective as $5000 \mathrm{ppm} \mathrm{GA}_{3}$. Overall, 5000 ppm GA $3 \mathrm{G} \mathrm{H}_{2} \mathrm{O}_{2}$, and $0.1 \mathrm{M} \mathrm{HNO}_{3}$ were significantly more efficient in enhancing percentage germination for both Basmati 370 and BW 196 rice varieties (Table 4). In addition, pre-treatment of the seeds with these concentrations also resulted in the most vigorous seedlings (Table 5). There were significant $(\mathrm{P} \leq 0.05)$ differences among the treatments and varieties in regards to seedling length. Variety BW 196 had longer seedlings compared to those of Basmati 370. The longest seedlings were of BW 196 treated with 2000 ppm $\mathrm{GA}_{3}$, while the shortest were those of Basmati 370 treated with $5 \mathrm{M} \mathrm{H}_{2} \mathrm{O}_{2}$.

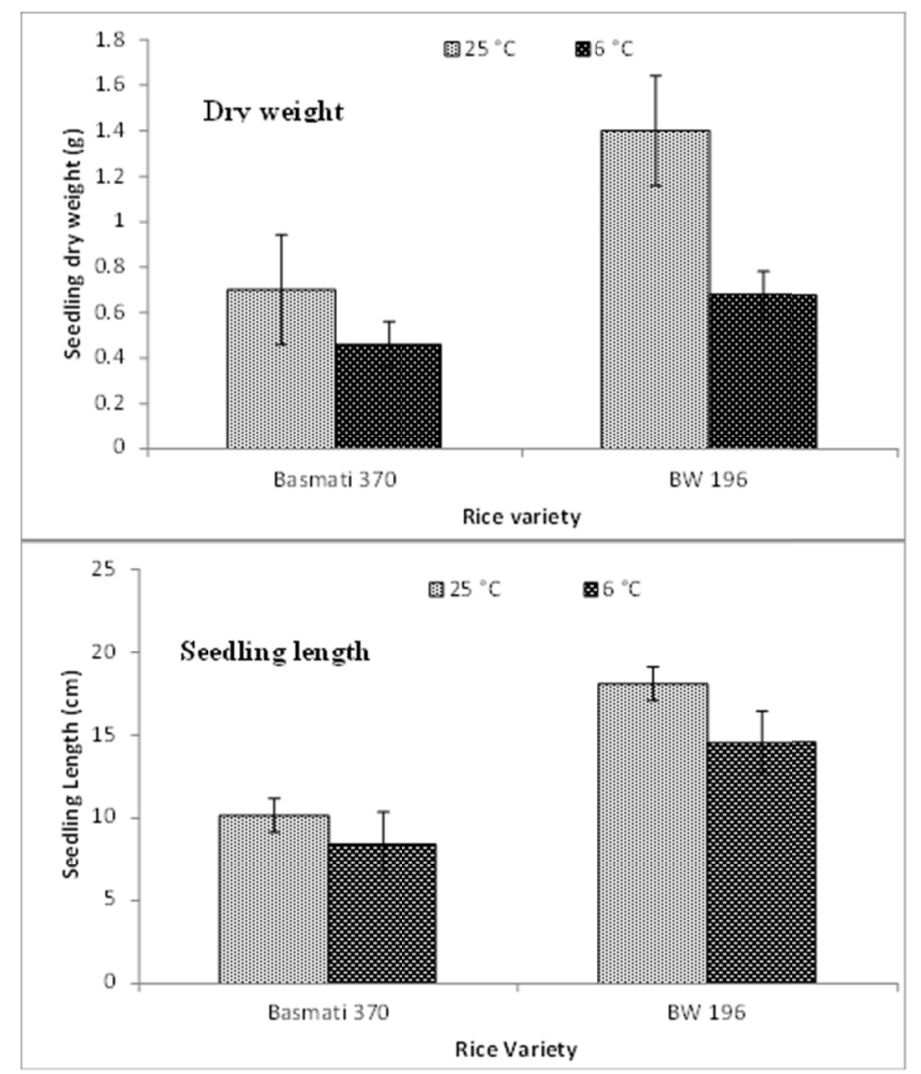

Figure 1. Dry weight and length of seedlings from seeds of two rice varieties treated with different chemical and physical treatments and stored at $25^{\circ} \mathrm{C}$ and at $6{ }^{\circ} \mathrm{C}$

Pre-treatment of the seeds with $\mathrm{GA}_{3}, \mathrm{HNO}_{3}$ and $\mathrm{H}_{2} \mathrm{O}_{2}$ also resulted in faster germination in both rice varieties (Figure 2). Gibberellic acid at 5000 ppm resulted in up to $91 \%$ germination in rice variety Basmati 370 by the second day after planting. No germination was observed in the untreated Basmati 370 seeds until 8 days after planting. The treatment which had the most vigorous seedling was 2000 ppm $\mathrm{GA}_{3}$, while control had the least vigorous. In Basmati 370 the highest vigour was observed on seeds treated with 5000 ppm $\mathrm{GA}_{3}$, while in $\mathrm{BW}$ 196 it was those treated with $2000 \mathrm{ppm} \mathrm{GA}_{3}$. 
Table 4. Percentage germination and speed germination index of two rice varieties under different treatments to break dormancy

\begin{tabular}{|c|c|c|c|c|c|c|}
\hline \multirow{2}{*}{ Treatment } & \multicolumn{3}{|c|}{ Germination } & \multicolumn{3}{|c|}{ Speed Germination Index } \\
\hline & Basmati 370 & BW 196 & Mean & Basmati 370 & BW 196 & Mean \\
\hline $0.1 \mathrm{M} \mathrm{HNO}_{3}$ & $90.0 \mathrm{bcd}$ & $92.7 \mathrm{abc}$ & 91.3 & 59.4 & 59.8 & 59.6 \\
\hline $0.2 \mathrm{M} \mathrm{HNO}_{3}$ & $82.0 \mathrm{e}$ & $68.7 \mathrm{f}$ & 75.3 & 50.8 & 38.1 & 44.5 \\
\hline $0.5 \mathrm{M} \mathrm{HNO}_{3}$ & $0.0 \mathrm{k}$ & $0.0 \mathrm{k}$ & 0.0 & 0.0 & 0.0 & 0.0 \\
\hline $1 \mathrm{M} \mathrm{HNO}_{3}$ & $0.0 \mathrm{k}$ & $0.0 \mathrm{k}$ & 0.0 & 0.0 & 0.0 & 0.0 \\
\hline $2 \mathrm{M} \mathrm{HNO}_{3}$ & $0.0 \mathrm{k}$ & $0.0 \mathrm{k}$ & 0.0 & 0.0 & 0.0 & 0.0 \\
\hline $0.5 \mathrm{M} \mathrm{H}_{2} \mathrm{O}_{2}$ & $42.0 \mathrm{~g}$ & $93.3 \mathrm{abc}$ & 67.7 & 18.3 & 102.4 & 60.4 \\
\hline $1 \mathrm{M} \mathrm{H}_{2} \mathrm{O}_{2}$ & $31.3 \mathrm{~h}$ & $94.7 \mathrm{abc}$ & 63.0 & 20.5 & 105.6 & 63.1 \\
\hline $2 \mathrm{M} \mathrm{H}_{2} \mathrm{O}_{2}$ & $83.3 \mathrm{de}$ & $97.3 \mathrm{ab}$ & 90.3 & 54.5 & 62.2 & 58.4 \\
\hline $3 \mathrm{M} \mathrm{H}_{2} \mathrm{O}_{2}$ & $26.7 \mathrm{hi}$ & $98.7 \mathrm{a}$ & 62.7 & 16.5 & 63.3 & 39.9 \\
\hline $5 \mathrm{M} \mathrm{H}_{2} \mathrm{O}_{2}$ & $10.7 \mathrm{j}$ & $95.3 \mathrm{ab}$ & 53.0 & 4.3 & 61.5 & 32.9 \\
\hline 1000 ppm GA 3 & 26.0hi & $92.7 \mathrm{abc}$ & 59.3 & 15.9 & 96.6 & 55.8 \\
\hline 2000 ppm GA 3 & $86.7 \mathrm{cde}$ & $98.7 \mathrm{a}$ & 92.7 & 74.2 & 64.6 & 69.4 \\
\hline 5000 ppm GA 3 & $93.3 \mathrm{abc}$ & $98.0 \mathrm{ab}$ & 95.7 & 105.6 & 62.6 & 84.1 \\
\hline Dry heat $\left(50{ }^{\circ} \mathrm{C}\right)$ & $0.0 \mathrm{k}$ & $0.0 \mathrm{k}$ & 0.0 & 0.0 & 0.0 & 0.0 \\
\hline Control & $21.3 \mathrm{i}$ & $80.0 \mathrm{e}$ & 50.7 & 2.1 & 17.8 & 10.0 \\
\hline $\mathrm{SD}$ & 35.8 & 41.3 & 35.1 & 31.8 & 36.6 & 28.4 \\
\hline $\operatorname{LSD}(\mathrm{V})$ & & & 4.9 & & & 1.79 \\
\hline $\operatorname{LSD}(\mathrm{T})$ & & & 1.8 & & & 4.91 \\
\hline $\mathrm{LSD}\left(\mathrm{T}^{*} \mathrm{~V}\right)$ & & & 7.1 & & & 6.95 \\
\hline CV $(\%)$ & & & 11.6 & & & 15.8 \\
\hline
\end{tabular}

Note. $\mathrm{HNO}_{3}=$ Nitric acid, $\mathrm{H}_{2} \mathrm{O}_{2}=$ Hydrogen peroxide, $\mathrm{GA}_{3}=$ Gibberellic acid, ppm = parts per million, Means followed by the same letter(s) in each column are not significantly different at $\mathrm{p} \leq 0.05, \mathrm{SD}=$ standard deviation, $\mathrm{LSD}=$ Least Significant Difference at $5 \%, \mathrm{CV} \%=$ co-efficient of variation

Table 5. Seedling lengths and vigour for Basmati 370 and BW 196 under different treatments to break dormancy

\begin{tabular}{|c|c|c|c|c|c|c|}
\hline \multirow{2}{*}{ Treatment } & \multicolumn{3}{|c|}{ Seedling lengths $(\mathrm{cm})$} & \multicolumn{3}{|c|}{ Seedling vigor index } \\
\hline & Basmati 370 & BW 196 & Mean & Basmati 370 & BW 196 & Mean \\
\hline $0.1 \mathrm{M} \mathrm{HNO}_{3}$ & 8.9 & 11.4 & 10.2 & $6.5 f$ & $8.5 \mathrm{~d}$ & 7.5 \\
\hline $0.2 \mathrm{M} \mathrm{HNO}_{3}$ & 7.0 & 11.5 & 9.3 & $4.5 \mathrm{~h}$ & $5.9 \mathrm{fg}$ & 5.2 \\
\hline $0.5 \mathrm{M} \mathrm{HNO}_{3}$ & 0.0 & 0.0 & 0.0 & 0.01 & 0.01 & 0.0 \\
\hline $1 \mathrm{M} \mathrm{HNO}_{3}$ & 0.0 & 0.0 & 0.0 & 0.01 & 0.01 & 0.0 \\
\hline $2 \mathrm{M} \mathrm{HNO}_{3}$ & 0.0 & 0.0 & 0.0 & 0.01 & 0.01 & 0.0 \\
\hline $0.5 \mathrm{M} \mathrm{H}_{2} \mathrm{O}_{2}$ & 5.7 & 11.3 & 8.5 & $1.4 \mathrm{jk}$ & 10.21 & 5.8 \\
\hline $1 \mathrm{M} \mathrm{H}_{2} \mathrm{O}_{2}$ & 5.2 & 9.0 & 7.1 & $1.2 \mathrm{jkl}$ & $8.4 \mathrm{~d}$ & 4.8 \\
\hline $2 \mathrm{M} \mathrm{H}_{2} \mathrm{O}_{2}$ & 7.3 & 10.7 & 8.9 & $4.9 \mathrm{gh}$ & $8.3 \mathrm{~d}$ & 6.6 \\
\hline $3 \mathrm{M} \mathrm{H}_{2} \mathrm{O}_{2}$ & 7.0 & 10.7 & 8.9 & $1.5 \mathrm{j}$ & $8.5 \mathrm{~d}$ & 5.0 \\
\hline $5 \mathrm{M} \mathrm{H}_{2} \mathrm{O}_{2}$ & 2.4 & 10.2 & 6.3 & $0.1 \mathrm{kl}$ & $7.8 \mathrm{~d}$ & 4.0 \\
\hline 1000 ppm $\mathrm{GA}_{3}$ & 5.0 & 8.2 & 6.6 & $0.9 \mathrm{jkl}$ & $7.3 \mathrm{de}$ & 4.1 \\
\hline 2000 ppm $\mathrm{GA}_{3}$ & 7.5 & 19.5 & 13.5 & $5.6 \mathrm{fgh}$ & $15.5 \mathrm{a}$ & 10.6 \\
\hline 5000 ppm $\mathrm{GA}_{3}$ & 8.4 & 15.7 & 12.0 & $7.7 \mathrm{~d}$ & $12.2 \mathrm{~b}$ & 10.0 \\
\hline Dry heat $\left(50^{\circ} \mathrm{C}\right)$ & 0.0 & 0.0 & 0.0 & 0.01 & 0.01 & 0.0 \\
\hline Control & 3.1 & 9.9 & 6.5 & $0.2 \mathrm{kl}$ & $3.2 \mathrm{i}$ & 1.7 \\
\hline $\mathrm{SD}$ & 3.2 & 5.8 & 4.4 & 2.6 & 4.6 & 3.4 \\
\hline $\operatorname{LSD}(\mathrm{V})$ & & & 0.408 & & & 0.323 \\
\hline $\operatorname{LSD}(\mathrm{T})$ & & & 1.118 & & & 0.883 \\
\hline LSD $(\mathrm{T} * \mathrm{~V})$ & & & 1.581 & & & 1.249 \\
\hline CV $(\%)$ & & & 21.3 & & & 25.2 \\
\hline
\end{tabular}

Note. $\mathrm{HNO}_{3}=$ Nitric acid, $\mathrm{H}_{2} \mathrm{O}_{2}=$ Hydrogen peroxide, $\mathrm{GA}_{3}=$ Gibberellic acid, ppm = parts per million, Means followed by the same letter(s) in each column are not significantly different at $\mathrm{p} \leq 0.05, \mathrm{SD}=$ standard deviation, $\mathrm{LSD}=$ Least Significant Difference at $5 \%, \mathrm{CV} \%=$ co-efficient of variation . 


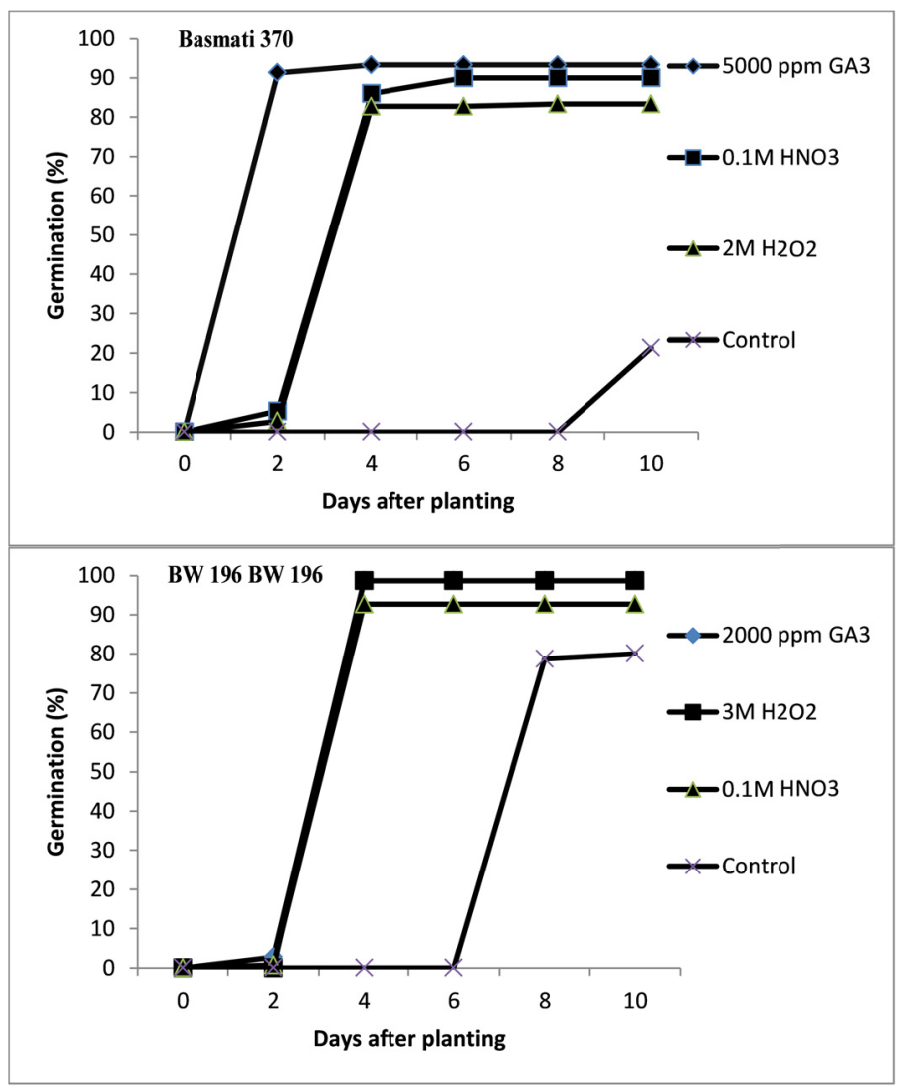

Figure 2. Percent germination over time for Basmati 370 and BW 196 rice varieties after pre-treatment with acid, growth regulator and peroxide

\section{Discussion}

Seeds stored in polythene and cheese cloth exhibited higher germination, seedling dry weight and length as compared to the other packaging materials tested. Storage temperature affected seed germination as indicated by higher germination in seeds stored at room temperature $\left(25^{\circ} \mathrm{C}\right)$. Similar findings are reported by Raikar et al. (2011) that rice seeds stored in polythene had higher germination percentage, seedling length, seedling vigour index and dry weight. However, Kishore et al. (2014) reported that pea seeds stored in polythene, paper, gunny and cloth bags had reduced germination with an increase in time. They, however, found that polythene was the best-suited material followed by paper, gunny and cloth bags. Various studies have also reported that storing seeds in polythene or plastic containers resulted in maximum germination and seedling vigour (Choudhury et al., 2011; Kamara et al., 2014). However, Owalade et al. (2011) reported that sorghum seeds stored in polythene bags had the least germination while Wani et al. (2014) reported that maize stored in cloth bag resulted in maximum germination while poly bag had the least. Naguib et al. (2011) reported maximum germination and seedling vigour in wheat seeds stored in aluminium and polyester while plastic and cloth bags had the least germination and seedling vigour. The improved germination of seeds stored in polythene bags could be due to moisture retention which ensures that the seeds remain viable. The moisture content of stored seed varies depending on the packaging material with seeds packaged in poly bag retaining the highest moisture content while seeds packaged in cloth bag retain the least moisture (Wani et al., 2014).

Higher germination in polythene bags may be due to its ability to accumulate carbon dioxide a By-product of respiration. Carbon dioxide replaces oxygen, therefore, lowering the rate of respiration and thus increasing storage longevity (McCormack, 2004). It could also be due to the preservation of seed moisture thus preventing the seed from over drying which may be destructive to the seed. Compared to the other materials used polythene bag provided an air tight environment hence the reason for higher germination percentage. Tang and Ngome (2015) reported that moisture content increased in rice seeds stored in polythene bags but the seeds showed reduced germination. The highest germination was observed in jute and paper bags. During storage, there are changes in seed moisture content and temperature which affects seed germination. Low movement of air in stored seeds lowers their quality due to heat accumulation resulting from respiration (Chattah et al., 2012). Seeds 
are naturally hygroscopic and therefore, moisture and vapour proof containers are recommended for storage of seed in order to maintain quality (Raikar et al., 2011). Of the two varieties used in this study, BW 196 had higher percentage germination and more vigorous seedlings than Basmati 370 . This could be due to the high degree of dormancy experienced in Basmati variety immediately after harvest which can last up to three months (Kumar et al., 2009). According to Waheed et al. (2012) degree of dormancy varies from or cultivar to another. The variation in seed vigour may also be due to variations in temperature, moisture content, relative humidity and pathogen activity in the different packaging materials (Raikar et al., 2011).

Pre-treatments of rice seeds with nitric acid, gibberellic acid and hydrogen peroxide enhanced germination and seedling vigour. Increasing the concentrations of the different treatments up to certain levels enhanced seedling germination. Higher concentrations of more than $0.2 \mathrm{M}$ nitric acid inhibited germination, the most effective being $0.1 \mathrm{M}$. However, increasing the concentration of hydrogen peroxide up to $2 \mathrm{M}$ and gibberellic acid up to $5000 \mathrm{ppm}$ was observed to improved germination and seedling vigour. Heat treatment at $50{ }^{\circ} \mathrm{C}$ completely inhibited germination. The results indicated that pre-treatment of freshly harvested rice seeds with acid, peroxide or growth hormone can break dormancy. Treatment with $5000 \mathrm{ppm}$ of gibberellic acid was found to have the highest germination on Basmati 370 while 1 M hydrogen peroxide acted best on BW 196. Similar findings have been reported by Vieira et al. (2002) who observed that treatment of rice seeds with gibberellic acid promoted germination while Patel and Mankad (2014) showed that the higher the concentration of $\mathrm{GA}_{3}$, the more rapid the germination. They found that gibberellic acid at $5000 \mathrm{ppm}$ resulted in $94 \%$ germination, while $3000 \mathrm{ppm} \mathrm{GA}$ gave $91 \%$ in seeds of Tithonia rotundifolia Blake. Aliloo and Darabinejad (2013) found that seedling length of Heliotropium europaeum varied depending on the dormancy breaking treatments used. Waheed et al. (2012) and Naredo et al. (1998) reported that hydrogen peroxide, nitric acid and gibberellic acid promoted seed germination in both wild and cultivated rice species. They noted that the different concentrations used had variable responses among the varieties. Munawar et al. (2015) reported that treatment of seeds with dry heat completely suppressed germination. However, Seshu and Dadlani (1991) reported that dry heat was effective in breaking dormancy on rice seed. According to findings by Kumar et al. (2009), the inability of treating Basmati 370 with $45^{\circ} \mathrm{C}$ for 72 hours to break dormancy could be due to the fact that the dormancy is hull imposed.

In the present study, the degree of dormancy varied depending on the rice variety. Variety BW 196 had weaker dormancy compared to Basmati 370 as indicated by higher germination percentages observed in the former. Many rice varieties have high dormancy at fresh harvesting stage. This is in agreement with Aliloo and Darabinejad et al. (2013) who found that dormancy in Heliotropium europae was high at harvesting stage. In rice, dormancy may be due to impermeable seed coat or factors related to the embryo (Kumar et al., 2009; Seshu \& Dadlani, 1991). Early or late harvesting affects seed maturity consequently affecting germination and dormancy (Samarah et al., 2004; Tung \& Serrano, 2011). Some of the most commonly used methods of breaking dormancy include mechanical and chemical scarification like the use of acids, soaking in water (Ali et al., 2011; Kimura \& Islam, 2012; Mousavi et al., 2011; Rouhi et al., 2015; Waheed et al., 2012). Physical dormancy may be easily overcome by making the seed coat permeable by use of heat (Waheed et al., 2012). However, to break physiological dormancy the seeds must be exposed to chemical treatments such as gibberellic acids (Rouhi et al., 2015). Acid scarification is one of the commonly used methods in breaking dormancy (Kimura \& Islam, 2012). Depending on the concentration and duration of exposure, the acids are able to dissolve the seed coat hence promoting germination (Mousavi et al., 2011; Ali et al., 2011). The high germination observed due to the use of $\mathrm{H}_{2} \mathrm{O}_{2}$ and $\mathrm{HNO}_{3}$ may be due to the breaking of the seed coat (Ali et al., 2011) which contains lignin and other compounds that make it impermeable to water and gases. The chemicals used may also leach away some of the growth inhibitors thus encouraging germination (Musara et al., 2015). The degree of scarification varies among cultivars and acid concentration (Kimura \& Islam, 2012). The composition of the seed coat is dependent on the crop and cultivar. From the study, it can be said that dormancy in both varieties was seed coat imposed. This is because it was easily broken by use of acid scarification. In this study, seeds treated with gibberellic acid were the most vigorous which was evident in enhanced seedling length and vigor index. The enhanced seedling vigor may be due to the role of gibberellic acid as a growth hormone which promotes root and shoot development. Gibberellic acid stimulates germination of root and shoots in seeds by weakening tissues barriers such as seed coat, by releasing hydrolytic enzymes hence allowing embryo enlargement (Rouhi et al., 2015; Pallavi et al., 2014; Vieira et al., 2002). It also acts by balancing the concentration of abscisic acid in the seed which is a growth inhibitor thus promoting germination (Viera et al., 2002). In the present study, the use of $0.5 \mathrm{M}, 1 \mathrm{M}, 2 \mathrm{M}$ nitric acid and dry heat at $50{ }^{\circ} \mathrm{C}$ completely suppressed germination in both rice varieties. This may be due to seed injury which may occur due to high concentration of the treatment or long durations of exposure (Kimura \& Islam, 2012; Musara et al., 2015). 


\section{Conclusion}

The findings of the study showed that the type of packaging material and dormancy plays a vital role in the maintenance of rice seed viability. Packaging the rice seed in polythene and cheese cloth was found to maintain the highest viability for up to three months of storage. However, the ideal packaging material for storing seed will depend on the crop and the physiological state of the seed. The study also showed that treating seeds of Basmati 370 gibberellic acid at $5000 \mathrm{ppm}$, hydrogen peroxide at $2 \mathrm{M}$ or nitric acid at $0.1 \mathrm{M}$ will break the dormancy and allow farmers to plant seeds shortly after harvest. This would increase rice crop productivity especially under irrigated conditions where farmers may be able to grow up to two crop cycles per year. This will alleviate the shortage of quality seeds of superior rice varieties such as aromatic Basmati. The breaking of dormancy of the superior varieties will also improve crop stands and yields per unit area.

\section{Acknowledgements}

This publication was made possible through financial support provided by the Alliance for a Green Revolution in Africa (AGRA) grant 2014 PASS 009. The opinions expressed herein are those of the author(s) and do not necessarily reflect the views of AGRA.

\section{References}

Ali, H. H., Tanveer, A., Nadeem, A. M., \& Asghar, H. N. (2011). Method to break seed dormancy of Rhynchosia capitata, a summer annual weed. Chilean Journal of Agricultural Research, 71(3), 483-487. https://doi.org/ 10.4067/s0718-58392011000300021

Aliloo, A. A., \& Darabinejad, S. (2013). Evaluation of different techniques for breaking seed dormancy of Heliotropium europaeum L. (Boraginanaceae). Journal of Biological and Environmental Sciences, 7(20), 87-91. Retrieved from http://jbes.uludag.edu.tr/PDFDOSYALAR/20/mak05.pdf

Chattha, S. H., Jamali, L. A., Ibupoto, K. A., \& Mangio, H. R. (2012). Effect of different packing materials and storage conditions on the viability of wheat seed (TD-1 variety). Science, Technology and Development, 31(1), 10-18. Retrieved from http://std.com.pk/archivedetails.php?vol=32\&year=2013\&issue=1\&issue no $=13$

Choudhury, M. M., Rajanna, C. M., Teixeira Da Silva, J. A., \& Balakrishna. (2011). Influence of Packaging Materials and Seed Treatments on Physiological Attributes during Storage of Rice (Oryza sativa L.). Seed Science and Biotechnology, 5(1), 15-20. Retrieved from https://www.researchgate.net/publication/283622 493_Influence_of_Packaging_Materials_and_Seed_Treatments_on_Physiological_Attributes_during_Stora ge_of_Rice_Oryza_sativa_L

Emongór, R. A., Mureithi, F. M., Ndirangu, S. N., Kitaka, D. M., \& Walela, B. M. (2009). The Rice Value Chain in Kenya with Reference to Rice Producers. Retrieved from http://knowledge.cta.int/Dossiers/Commodities/ Rethinking-the-rice-value-chain/Relevant-publications/The-rice-value-chain-in-Kenya-with-reference-to-ric e-producers

Islam, R., Mukherjee, A., \& Hossin, M. (2012). Effect of osmopriming on rice seed germination and seedling growth. Journal of the Bangladesh Agricultural University, 10(1), 15-20. https://doi.org/10.3329/jbau.v10 i1.12013

Jyoti, \& Malik, C. P. (2013). Seed deterioration: A review. International Journal of Life Sciences Biotechnology and Pharma Research, 2(3), 374-385. Retrieved from http://new.ijlbpr.com/view.php?iid=369

Kamara, E. G., Massaquoi, F. B., James, M. S., \& George, A. (2014). Effects of packaging material and seed treatment on Weevil (Callosobruchus maculatus (F) Coleoptera: Bruchidae) infestation and quality of cowpea seeds. African Journal of Agricultural Research, 9(45), 3313-3318. https://doi.org/10.5897/AJAR 2014.8821

Kimura, E., \& Islam, M. A. (2012). Seed scarification methods and their use in forage legumes. Research Journal of Seed Science, 5(2), 38-50. https://doi.org/10.3923/rjss.2012.38.50

Kishore, A., Kumar, A., \& Chaurasia, A. L. (2014). Effect of packaging material on seed viability and vigour of stored field pea genotypes. Annals of Agric Bio Research, 27(2), 181-186. Retrieved from http://www.cabdirect.org/abstracts/20143199295.html

Kumar, M., Rajpurohit, D., Basha, P. O., Bahlla, A., Randhwa, G. S., \& Dhaliwal, H. S. (2009). Genetic control of seed dormancy in Basmati rice. Madras Agricultural Journal, 96(7-12), 305-308. Retrieved from 
https://www.researchgate.net/profile/Deepak_Rajpurohit/publication/264942788_Genetic_Control_of_Seed _Dormancy_in_Basmati_Rice/links/53f727bc0cf22be01c453699.pdf?origin=publication_detail

Mbofung, G. C. Y., Goggi, A. S., Leandro, L. F. S., \& Mullen, R. E. (2013). Effects of storage temperature and relative humidity on viability and vigor of treated soybean seeds. Crop Science, 53(3), 1086-1095. https://doi.org/10.2135/cropsci2012.09.0530

McCormark, J. H. (2004). Principles and practices of seed harvesting, processing, and storage: An organic seed production manual for seed growers (94305: 28). Creative Commons. Stanford, California. Retrieved from http://www.carolinafarmstewards.org/wp-content/uploads/2012/05/SeedProcessingandStorageVer_1pt3.pdf

Ministry of Agriculture. (2009). Government of Kenya, National Rice Development Strategic Plan (NRDS) (2008-2018). Retrieved from https://www.jica.go.jp/english/our_work/thematic_issues/agricultural/pdf/ kenya_en.pdf

Mousavi, S. R., Rezaei, M., \& Mousavi, A. (2011). A general overview on seed dormancy and methods of breaking it. Advances in Environmental Biology, 5(10), 3333-3337. Retrieved from https://www.research gate.net/publication/216472635_A_General_Overview_on_Seed_Dormancy_and_Methods_of_Breaking_It

Muangkaeo, R., Srichuwong, S., \& Vearasilp, S. (2005). Influence of Packaging Materials and Storage Time on Seed Viability and Chemical Component of Rice Seed. Conference on International Agricultural Research for Development held from $11^{\text {th }}-13^{\text {th }}$ October 2005, Stuttgart-Hohenheim Germany. Retrieved from http://www.tropentag.de/2005/abstracts/full/268.pdf

Munawar, S., Naeem, M., Ali, H. H., Jamil, M., Iqbal, M., Nazir, M. Q., .. Safdar, M. E. (2015). Seed dormancy breaking treatments for African purslane (Zaleya pentandra). Planta Daninha, 33(4), 623-629. https://doi.org/10.1590/s0100-83582015000400001

Musara, C., Chitamba, J., \& Nhuvira, C. (2015). Evaluation of different seed dormancy breaking techniques on okra (Abelmoschus esculentus L.) seed germination. African Journal of Agricultural Research, 10(17), 1952-1956. https://doi.org/10.5897/ajar2014.9181

Naguib, N. A., Mohamed, E. A. I., \& El-Aidy, N. A. (2011). Effect of storage and packaging material on wheat (Triticum aestivum L.) seed viability and quality. Egypt Journal of Agricultural Research, 89(4), 1481-1497. Retrieved from http://www.arc.sci.eg/ejar/UploadFiles/Publications/139672\%D8\%A7\%D9\%84\%D8\%A8\% D8\%AD\%D8\%AB\%20\%D8\%A7\%D9\%84\%D8\%AE\%D8\%A7\%D9\%85\%D8\%B3\%20\%D9\%85\%D8\%A D\%D8\%A7\%D8\%B5\%D9\%8A\%D9\%84\%20\%D8\%AD\%D9\%82\%D9\%84\%D9\%8A\%D9\%87.pdf

Naredo, M. E. B., Juliano, A. B., Lu, B. R., De Guzman, F. L. O. R. A., \& Jackson, M. T. (1998). Responses to seed dormancy-breaking treatments in rice species (Oryza L.). Seed Science and Technology, 26(3), 675-689. Retrieved from https://www.researchgate.net/file.PostFileLoader.html?id=58289fa1615e27e82602 bfa6\&assetKey $=$ AS\%3A428011544682497\%401479057313009

Nasreen, S., Khan, M. A., Zia, M., Ishaque, M., Uddin, S. A. L. E. E. M., Arshad, M., \& Rizvi, Z. F. (2015). Response of sunflower to various pre-germination techniques for breaking seed dormancy. Pakistan Journal of Botany, 47(2), 413-416. Retrieved from https://www.pakbs.org/pjbot/PDFs/47(2)/04.pdf

Onyango, A. O. (2014). Promotion of rice production: A likely step to making Kenya food secure. Assessment of current production and potential. Developing Country studies, 4(19), 26-31. Retrieved from http://www.iiste.org/Journals/index.php/DCS/article/view/16048

Owolade, O. F., Olasoji, J. O., \& Afolabi, C. G. (2011). Effect of storage temperature and packaging materials on seed germination and seed-borne fungi of sorghum (Sorghum bicolor (L.) Moench.) in South West Nigeria. African Journal of Plant Science, 5(15), 873-877. https://doi.org/10.5897/AJPS11.209

Pallavi, H. M., Vishwanath, K., Harish, B. S., Prashanth, Y., \& Thattimani, M. (2014). Seed treatments to break seed dormancy and Standardization of viability test procedure in Abrus precatorious. Journal of Medicinal Plants Research, 8(4), 229-236. https://doi.org/10.5897/jmpr2013.5102

Patel, R. G., \& Mankad, A. U. (2014). Effect of gibberellins on seed germination of Tithonia rotundifolia Blake. International Journal of Innovative Research in Science, Engineering and Technology, 3(3), 10680-10684. Retrieved from https://www.ijirset.com/upload/2014/march/103_EFFECT.pdf

Pradhan, B. K., \& Badola, H. K. (2012). Effect of storage conditions and storage periods on seed germination in eleven populations of Swertia chirayita: A critically endangered medicinal herb in Himalaya. The Scientific World Journal, 2012, 1-9. https://doi.org/10.1100/2012/128105 
Raikar, S. D., Vyakarnahal, B. S., Biradar, D. P., Deshipande, V. K., \& Janagoudar, B. S. (2011). Effect of seed source, containers and seed treatment with chemical and bio pesticide on storability of scented Rice Cultivars. Mugadsugandha. Karnataka Journal of Agricultural Sciences, 24(4), 448-454. Retrieved from http://www.inflibnet.ac.in/ojs/index.php/KJAS/article/viewFile/942/852

Rouhi, H. R., Sepehri, A., Sefidkhani, L., \& Karimi, F. (2015). Evaluation of several methods for breaking dormancy of bitter vetch seeds (Vicia ervilia L.). Plant Breeding and Seed Science, 71(1), 57-65. https://doi.org/10.1515/plass-2015-0022

Samarah, N. H., Allataifeh, N., Turk, M. A., \& Tawaha, A. M. (2004). Seed germination and dormancy of fresh and air-dried seeds of common vetch (Vicia sativa L.) harvested at different stages of maturity. Seed Science and Technology, 32(1), 11-19. https://doi.org/10.15258/sst.2004.32.1.03

Seshu, D. V., \& Dadlani, M. (1991). Mechanism of seed dormancy in rice. Seed Science Research, 1(03), 187-194. https://doi.org/10.1017/s0960258500000854

Tang, E. N., \& Ngome, A. F. (2015). Rice seed quality as influenced by storage duration and package type in Cameroon. International Journal of Biological and Chemical Sciences, 9(3), 1229-1242. https://doi.org/ 10.4314/ijbcs.v9i3.8

Tung, L. D., \& Serrano, E. P. (2011). Effects of warm water in breaking dormancy of rice seed. Omonrice, 18, 129-136. Retrieved from https://www.researchgate.net/file.PostFileLoader.html?id=58289c46eeae3930a46 578f8\&assetKey=AS\%3A428007945969666\%401479056454513

United States Agency for International Development. (2010). Staple Food Value Chain Analysis, Country-Report, Kenya. Retrieved from http://pdf.usaid.gov/pdf_docs/Pnadw641.pdf

Vange, T., Ikyeleve, F., \& Okoh, J. O. (2016). Effect of Packaging Materials and Storage Condition on Soybean Germination and Seedling Vigour in Makurdi. Research Journal of Seed Science, 9, 1-4. https://doi.org/ 10.3923/rjss.2016.1.4

Vieira, A. R., Vieira, M. D. G. G. C., Fraga, A. C., Oliveira, J. A., \& Santos, C. D. D. (2002). Action of gibberellic acid $\left(\mathrm{GA}_{3}\right)$ on dormancy and activity of alpha-amylase in rice seeds. Revista Brasileira de Sementes, 24(2), 43-48. https://doi.org/10.1590/s0101-31222002000200008

Waheed, A., Ahmad, H., \& Abbasi M. F. (2012). Different treatment of rice seed dormancy breaking, germination of both wild species and cultivated varieties (Oryza sativa L.). Journal of Materials and Environmental Science, 3(3), 551-560. Retrieved from http://www.jmaterenvironsci.com/Document/vol3/ vol3_N3/55-JMES-204-2012-Waheed.pdf

Wani, A. A., Joshi, J., Titov, A., \& Tomar, D. S. (2014). Effect of seed treatments and packing materials on seed quality parameters of maize (Zea mays L.) during storage. Indian Journal of Applied Research, 4(4), 40-44. https://doi.org/10.15373/2249555x/apr2014/10

Whitehouse, K. J., Hay, F. R., \& Ellis, R. H. (2015). Increases in the longevity of desiccation-phase developing rice seeds: Response to high-temperature drying depends on harvest moisture content. Annals of Botany, 116, 247-259. https://doi.org/10.1093/aob/mcv091

Wu, T., Yang, C., Ding, B., Feng, Z., Wang, Q., He, J., ... Wan, J. (2016). Microarray-based gene expression analysis of strong seed dormancy in rice cv. N22 and less dormant mutant derivatives. Plant Physiology and Biochemistry, 99, 27-38. https://doi.org/10.1016/j.plaphy.2015.12.001

\section{Copyrights}

Copyright for this article is retained by the author(s), with first publication rights granted to the journal.

This is an open-access article distributed under the terms and conditions of the Creative Commons Attribution license (http://creativecommons.org/licenses/by/4.0/). 